\title{
Domestic Interests and Control Regimes
}

\section{Citation}

Bates, Robert H. 2007. Domestic Interests and Control Regimes. In Vol. 1 of The Political Economy of Economic Growth in Africa, 1960-2000, ed. Benno J. Ndulu, Stephen A. O'Connell, Robert H. Bates, Paul Collier, and Chukwuma C. Soludo, 175-201. Cambridge: Cambridge University Press.

\section{Permanent link}

http://nrs.harvard.edu/urn-3:HUL.InstRepos:12214834

\section{Terms of Use}

This article was downloaded from Harvard University's DASH repository, and is made available under the terms and conditions applicable to Other Posted Material, as set forth at http:// nrs.harvard.edu/urn-3:HUL.InstRepos:dash.current.terms-of-use\#LAA

\section{Share Your Story}

The Harvard community has made this article openly available.

Please share how this access benefits you. Submit a story.

Accessibility 


\title{
$4 \mid$ Domestic interests and control regimes
}

\author{
Robert H. Bates
}

1 Introduction page 176

2 Prices in the macroeconomy 176

3 Interventions by sector $\quad 177$

3.1 The industrial sector $\quad 177$

$\begin{array}{ll}3.2 \text { The agricultural sector } & 178\end{array}$

4 The economic impact 179

5 A closer look 181

5.1 Manufacturing $\quad 181$

5.2 Public services $\quad 182$

$\begin{array}{lll}5.3 & \text { Farming } & 183\end{array}$

6 Temporal and political correlates $\quad 185$

6.1 A closer look 188

7 The politics of economics 190

7.1 A fruitful paradox 191

$\begin{array}{lll}7.2 & \text { Regional redistribution } & 192\end{array}$

7.3 Discussion 194

8 Conclusion $\quad 195$

References 198

The paper was written with financial support from the National Science Foundation (Grant SES 9905568), the Carnegie Corporation, and the Center for International Development and the Weatherhead Center for International Affairs of Harvard University. The chapter was written while the author was a Moore Distinguished Scholar at the California Institute of Technology. The chapter has benefited greatly from comments and criticisms received at seminars held at Harvard University, Guelo Brittany, and at the annual meetings of the AERC 2004 in Nairobi. Special thanks go to Steven Block for his criticisms and corrections. As ever, Karen Ferree and Smita Singh deserve much of the credit for this work. James Habyarimana and Irene Yackolev provided valuable contributions. I wish to thank Bela Prasad, Matthew Hindeman, and Marc Alexander for their technical assistance. The author alone is to be blamed for its shortcomings. 


\section{Introduction}

When imposing a control regime, a government seeks to displace the market as the primary agency for governing the economy. Either by manipulating the structure or operation of markets, or by replacing private markets with public bureaucracies, it seeks to shape the way in which land, labor, and capital are allocated; commodities produced and distributed; services furnished; and incomes determined.

This chapter details the policies that characterize regulatory regimes and documents their economic impact. Stressing the economic costs inflicted by the imposition of control regimes, the chapter asks: given their magnitude, why did governments pursue such policies? And having chosen to regulate their economies, why did governments persist in this decision? The answers it offers not only shed light on why governments may impose control regimes, then, but also on the politics of policy reform.

In analyzing the content of control regimes, this chapter draws on two sets of data. One is the classification of policy syndromes developed by the research teams; the other is an account of the policy choices of twentyeight African governments published by the World Bank (1994). ${ }^{1}$ In its 1994 report, the Bank audited the measures taken by its sample set of governments to regulate financial markets, industries, trade, and services. To illustrate the content of control regimes, the chapter compares the measures taken by governments judged to have implemented control regimes with those judged not to have done so, as documented in the World Bank's report (1994).

\section{Prices in the macroeconomy}

As shown in the World Bank's report (1994), almost all African governments created banks to promote investment in commerce, industry, and agriculture. Governments that imposed control regimes went further, however: targeting privileged sectors, they actively subsidized the costs of capital for those who invested in them. To encourage investment, they imposed low interest rates, either by constraining the lending practices of private banks or by creating state banks to offer low-cost loans. The result was financial repression. As shown in table 4.1, under governments judged to have imposed control regimes, the mean ex ante real deposit interest rate was lower than under governments whose policies were judged to have remained "syndrome-free."

\footnotetext{
${ }^{1}$ See World Bank (1994).
} 
Table 4.1 Ex ante real deposit rate.

\begin{tabular}{lccc}
\hline & Control regimes & Other syndromes & Syndrome-free \\
\hline Mean & -66.1 & -309.6 & -3.9 \\
Median & -6.1 & -4.1 & -0.3 \\
Count & 162 & 90 & 165 \\
\hline
\end{tabular}

Table 4.2 Black market premium.

\begin{tabular}{lccc}
\hline & Control regimes & Other syndromes & Syndrome-free \\
\hline Mean & 175.4 & 133.6 & 7.4 \\
Median & 53.0 & 27.0 & 6.3 \\
Count & 317 & 211 & 314 \\
\hline
\end{tabular}

Governments that operate outside the CFA zone (or RMA) control the means of payment. By setting the price at which local currency exchanges for foreign, and then controlling transactions at this official exchange rate - e.g. via remittance requirements for exporters and foreign-exchange rationing for importers - they can separate local parallel-market prices for traded goods from international prices. One measure of the magnitude of this intervention is the level of the black market premium that then prevails in the market for foreign exchange. As shown in table 4.2, when governments imposed control regimes, the mean level of that premium was more than twice the level of that in economies free of controls. ${ }^{2}$

\section{Interventions by sector}

Governments that adopted regulatory regimes were not only more likely to distort prices fundamental to the macroeconomy; they were also more likely to champion sectoral policies.

\subsection{The industrial sector}

Those that adopted control regimes intervened heavily in the industrial sector. Data from the World Bank study (1994: 234) suggest that over onethird secured monopoly rights over mineral production, compared with one-quarter of those judged "syndrome-free." Similarly, the World Bank's data (1994: 234) indicate that governments that adopted control regimes

${ }^{2}$ Given the magnitude of the within-group variance, the difference in means implies an F-statistic of 5.44, significant at the 0.02 level. 
Table 4.3 Intervention in food markets. (number of countries)

\begin{tabular}{lcc}
\hline & \multicolumn{2}{c}{ Countries that adopt: } \\
\cline { 2 - 3 } Level of restrictions: & Control regimes & Other \\
\hline Major & 12 & 2 \\
Limited & 5 & 0 \\
None & 4 & 5 \\
Total & 21 & 7 \\
\hline
\end{tabular}

Source: Data from World Bank (1994: 85).

were half-again more likely to form state monopolies in the cement and textile industries.

\subsection{The agricultural sector}

As seen in table 4.3, in its review of twenty-eight African cases, the World Bank noted that one-half of the governments judged to have imposed control regimes, placed "major" - as opposed to "limited" or "no" - restrictions on the purchase and sale of staple food crops.

All twenty-eight of the governments studied by the World Bank maintained a monopoly over the purchase and export of their country's major cash crops. But by artificially appreciating the value of the domestic currency, governments that adopted control regimes imposed an additional level of taxation. As noted in a variety of studies (most notably, perhaps, in Krueger, Schiff, and Valdes 1992), the manipulation of the exchange rate powerfully and adversely impacted upon the earnings of those producing cash crops for export.

African governments also intervened in the market for food crops: the World Bank (1994) reports that virtually all of the twenty-eight governments in its sample imposed "extensive" price controls (1994: 91). The better to provision consumers with low-priced products, some governments secured monopoly standing in agricultural markets, thus gaining the power to alter prices. Examples would include the creation of the National Milling Corporation by the government in Tanzania, which purchased and processed wheat and maize; the Sugar Board in Kenya, which produced and processed sugar and regulated its distribution; or the National Agricultural Marketing Board in Zambia. Table 4.4 reveals that governments that adopted control regimes more frequently created such marketing agencies than did others. As noted in studies by Killick (1978), Bates and Collier (1991), and others, ${ }^{3}$

\footnotetext{
3 See, for example, Dodge (1977) and the classic reports of William Jones: World Bank $(1975,1982)$.
} 
Table 4.4 Government monopolies in the processing of wheat, maize, sugar, and vegetable oil.

(number of countries).

\begin{tabular}{lccccc}
\hline Countries that adopt: & Wheat & Maize & Sugar & Vegetable oil & Total \\
\hline Control regimes & 11 & 6 & 12 & 8 & 21 \\
Other policies & 2 & 2 & 4 & 2 & 7 \\
\hline
\end{tabular}

Source: Data from: World Bank (1994: 234).

Table 4.5 Government monopoly over the importation of wheat, rice, sugar, other staples, and vegetable oils.

(number of countries)

\begin{tabular}{|c|c|c|c|c|c|c|}
\hline Countries that adopt & Wheat & Rice & Sugar & $\begin{array}{l}\text { Other staple } \\
\text { food crops }\end{array}$ & $\begin{array}{c}\text { Vegetable } \\
\text { oils }\end{array}$ & Total \\
\hline Control regimes: & 10 & 13 & 13 & 8 & 8 & 21 \\
\hline Other policies: & 4 & 4 & 3 & 2 & 2 & 7 \\
\hline
\end{tabular}

Source: Data from World Bank (1994: 235).

when governments created agricultural marketing boards, they employed their market power to provision urban consumers with low-priced food.

In efforts to control domestic markets, governments also created public agencies that purchased food abroad and marketed it domestically. Acquiring foreign exchange at the official rate, the agencies purchased rice, wheat, and other products abroad, which they placed in the domestic market at prices lower than those that would have prevailed had the imports been made by private traders. As seen in table 4.5, the data suggest that such measures were more likely to have been taken by governments that adopted regulatory regimes.

To be noted and stressed is that the financial burden of such interventions was borne by exporters, a portion of whose earnings were appropriated at the official rate. In many African countries, agricultural products - coffee, cocoa, cotton, or other cash crops - numbered among the exports that financed these measures.

\section{The economic impact}

To address the impact of control regimes, we begin by mapping the incidence of these policies onto the opportunity structure of Africa's economies. As seen in 4.6, the governments in landlocked and coastal countries more 
Table 4.6 Control regimes and geographic location, 1970-1995.

\begin{tabular}{lcc}
\hline & Percent & Number \\
\hline Landlocked & 52.3 & 193 \\
Coastal & 49.6 & 183 \\
Resource-rich & 38.8 & 143 \\
\hline
\end{tabular}

Note: Because Resource-rich can be either coastal or landlocked, the total is omitted.

Source: Data supplied by Paul Collier and Stephen A. O'Connell, based on the classification developed in chapter 2.

frequently adopted regulatory policies than did those that were resourcerich.

In chapter 2, Collier and O'Connell measure the impact of control regimes on growth rates in Africa. Controlling for the impact of rainfall and fluctuations in the growth rate of major trading partners and introducing countryspecific effects - to control for such factors as coastal location or resource endowment - and period effects - to control for the effects of changes in the global economy, such as resulted from the oil price shocks of the 1970s and 1980s - Collier and O'Connell find that economies subject to control regimes achieved a median ${ }^{4}$ growth rate that lay nearly 2 percentage points below that achieved by economies governed by policies that were judged "syndrome-free."

As reported in chapter 3, Fosu and O'Connell (2006) disaggregate the average performance of Africa's economies into "growth spells," which they then relate to the policy choices of their governments. Defining a growth collapse as a fall in the three-year centered moving average of growth below the no-growth ( 0.0 percent) level, they find the frequency of growth collapses under control regimes to be more than twice that under policy regimes that remained syndrome-free. Defining "medium" growth as the achievement of a five-year moving average growth rate of 2.5 percent, Fosu and O'Connell (2006) find that in less than one-quarter of the cases where governments adopted control regimes did economies attain medium rates of growth; by contrast, where policies were syndrome-free, more than half attained such a growth rate. They further find that economies ruled by governments whose policies remained syndrome-free were more than twice as likely to attain high growth rates - a five-year moving average of 3.5 percent or more - than were those ruled by governments that imposed control regimes.

${ }^{4}$ Given the dispersion in the data, they employed a least-absolute rather than a least-squares deviation criterion, thus dampening the impact of outliers. 


\section{A closer look}

To illuminate the processes that account for the impact of control regimes, it is useful to move from aggregate, cross-national data to materials gleaned from country studies. In this section we make use of materials gathered at the micro-level, drawing heavily on the work of the country teams as reported in volume 2.

\subsection{Manufacturing}

Seeking to promote industrial development in Tanzania, the government placed a high priority on securing the local production of consumer products, such as clothing and footwear. The government therefore created the National Textile Corporation (TEXCO), which invested in a series of mills that produced cloth, blankets, and packaging, and the Tanzanian Leather Associated Industries (TLAIA), which invested in the production of shoes. None of the firms created by the two agencies operated at a profit. For want of revenues, their managers skimped on maintenance; they lacked access to the foreign exchange with which to import spare parts. The managers frequently failed to pay suppliers of raw materials, of services, or of the water and electricity necessary to drive looms and lathes. The firms survived by securing loans from the government: funneling money into the shoe plants, one minister declared, "was like pouring water down in a leaking tin" (McHenry 1994). Despite the poor performance of these firms, the government continued to make good their losses. From 1967, the date of Tanzania's official commitment to socialism, to 1982, when that commitment began to erode, public sector firms in Tanzania increased their share of total manufacturing employment from 15.5 percent to 52.7 percent. Fearing to lay off the thousands of workers that these firms employed (McHenry 1994), the government continued to use public revenues to cover their deficits.

As noted in the country studies in volume 2, Tanzania's experience was replicated by that in other nations. Addressing the case of Zambia, for example, Mwanawina and Mulungushi (2007) trace the government's investments in factories for the making of glass, the fabrication of building materials, the extrusion of plastics, and the assembly of automobiles. Quoting Turok (1979: 24) they note that "the parastatal sector, the main arm of government economic muscle, were grossly undercapitalized, over staffed, and faced shortages of raw materials and spare parts due to lack of foreign exchange" (2007: 18). Gogué and Evlo (2007) recount the efforts of the government of Togo: "Public investment represented nearly half of GDP by the end of the 1970s," they note (2005: 16). The government of Togo, 
Gogué and Evlo (2007) record, launched its program of industrialization following the influx of foreign revenues inspired by a boom in the price of phosphates. Similar stories are told for Cameroon and Congo (Kobou, Njinkeu, and Powo Fosso 2007; Tsassa and Yamb 2007); Burundi (Nkurunziza and Ngaruko 2007); Zambia (Mwanawina and Mulungushi 2007), and Sierra Leone (Davies 2007). As in the case of Tanzania, these investments often consumed more resources than they generated. Writing of the industries created by the government of Burundi, for example, Nkurunziza and Ngaruko (2007) note:

By 1995, equity capital of thirty-six such firms with majority state participation represented 20 percent of the country's GDP, but overall, these corporations posted a net loss equivalent to 6 percent of GDP. (Nkurunziza and Ngaruko 2007: 35)

\subsection{Public services}

Governments that imposed control regimes recruited large numbers of workers. Tsassa and Yamb (2007) report, for example, that the government of the Republic of the Congo increased the size of the public work force by an average of 9 percent per year from 1960 to 1993. Samba Mamadou and Yakoubou (2007) report a 4 percent annual increase in the government work force in Niger over the period 1980-92, while Gogué and Evlo (2007) note a three-fold increase in public sector employment in Togo over the period 1965-79. In Niger, Cameroon, Congo, Guinea, and Benin, the country studies inform us, in the 1960s and 1970s all who secured their diplomas were guaranteed employment by the state. ${ }^{5}$

Tsassa and Yamb (2007) report that by the early 1990s, 97 percent of the receipts of the government of the Congo were targeted for civil servant salaries. One way of relieving the burden was simply to accumulate arrears; the country studies suggest that this tactic was adopted by many of the governments in the franc zone. Where governments could exercise monetary discretion, they often reduced the burden by inflating the currency. According to the International Labour Organization (ILO), in Tanzania, the real salaries of public employees fell by nearly one-half between 1969 and 1980 (cited in McHenry 1994, table 4.1). In her study of workers in Kinshasa, MacGaffey (1991) reports that mid-1980s salaries constituted less than one-half of the incomes of those who worked in the public sector.

One of the major effects of the reduction of salaries was the growth of corruption. Charged with preventing the importation of products that were manufactured locally, a customs official could instead wave such goods through, pocketing a fee for his "service." Or charged with overseeing the

\footnotetext{
${ }^{5}$ Note the relevant country case studies. They are posted at http://www.aercAfrica.org.
} 
Table 4.7 Distribution of growth performance, by syndrome.

(\% of row)

\begin{tabular}{lccl}
\hline \multicolumn{4}{c}{ Panel A: three-year moving average } \\
Syndrome status & $<\mathbf{0}$ & $>=\mathbf{0}$ & Total \\
Not-free & 49.3 & 50.7 & 100 \\
Syndrome-free & 19.1 & 80.9 & 100 \\
Total & 39.5 & 60.5 & 100 \\
& \multicolumn{4}{c}{ Panel B: five-year moving average } \\
Syndrome status & $<\mathbf{2 . 5}$ & $>=\mathbf{2 . 5}$ & Total \\
Not-free & 75.9 & 24.1 & 100 \\
Syndrome-free & 47.5 & 52.6 & 100 \\
Total & 66.7 & 33.3 & 100 \\
& & & \\
Syndrome status & Panel C: five-year moving average & \\
Not-free & $<\mathbf{3 . 5}$ & $>=\mathbf{3 . 5}$ & Total \\
Syndrome-free & 80.7 & 19.3 & 100 \\
Total & 55.8 & 44.2 & 100 \\
\hline
\end{tabular}

pricing of products produced at home, an inspector could share with the managers of firms the profits to be made from selling those products on the black market. The result was the erosion of the quality of public services and the rise of corruption.

\subsection{Farming}

Governments that imposed control regimes formed monopsonies with which to purchase export crops; offering farmers a low domestic price, they re-sold cash crops at prices prevailing in global markets. Dossou and Sinzogan, with Mensah (2007) document the cartelization of the cotton industry in Benin and its subsequent take over by the government. They also document the government's use of its market power to separate the domestic from the international price of cotton and to appropriate a major portion of the differential. Azam and Djimtoïngar (2007) note a similar pattern in Chad, where the government not only imposed a direct tax on farmers but also a profit tax on the reserves of the cotton agency. By dint of the government's ownership of 75 percent of the shares of the parastatal, the majority of the profits also accrued to the government. Nkurunziza and Ngaruko (2007) provide a similar narrative for the coffee industry in Burundi; Samba Mamadou and Yakoubou (2007) for the groundnut industry in Niger; and Davies (2007) for coffee and cocoa in Sierra Leone. As stated by Gogué and Evlo (2005): 
The producer price of key export crops fell considerably ( $40 \%$ in the case of cocoa and $20 \%$ in the case of coffee) despite the increase in the international prices of these commodities. The power of the agencies created to implement the price control policies (OPAT, Togograin, Togofruit, etc.) grew bigger, as did the anti-rural bias of the government's income distribution policy. At the same time, flattering and deceiving slogans that boasted the merits of the Green Revolution and through which the government conveniently conveyed its demagogical rhetoric lulled farmers. Indeed, Togolese heard so much about something called "the Green Revolution" but they never experienced [it] actually. The beautiful words and great promises of the government were not followed by concrete actions. (2005: 36)

Similar patterns arose in markets for food crops. In Tanzania (Mwase and Ndulu 2007), Mozambique (de Sousa and Sulemane 2007), and Ethiopia (Alemayehu 2007), governments gathered farmers into villages, where they provided land, tools, and credit. With farm production now concentrated in circumscribed locations, the governments sought to control the purchase and distribution of farm products, funneling them through "single-channel" marketing structures, such as marketing boards or cooperative societies. They thereby sought to procure for urban consumers ample supplies of food at affordable prices. The result of this policy was, however, the opposite. As documented for Guinea by Doumbouya and Camara (2007) and for Tanzania by Lofchie (1989), as the bureaucracy charged with procuring grain increased in scope and size, the amount of grain that it marketed declined. One interpretation is that production itself declined; given the forceful relocation of peasant families from private farms to collective villages, this interpretation may be correct. Another is that when confronted with an official market offering low prices for farm products, the producers simply sold their products in unofficial markets, thereby eluding those who monitored the quantities and regulated the prices of agricultural products. The latter possibility is confirmed by Doumbouya and Camara (2007), who report the growth of black markets in Guinea and the movement of producers to regions by the border, where they could sell food crops in private markets and at unofficial rates of exchange. Indeed, in their study of Benin, Dossou and Sinzogan, with Mensah (2007) stress the size of the illicit trade in food products with Nigeria, where "Dutch disease" had led to high food prices.

Writing about Mozambique, Pitcher (2002) notes similar patterns. In the southern portion of Mozambique, the formation of communal villages so disrupted production that shortages of food and high prices for farm products became painfully common in the port cities and national capital, even while the welfare of the peasantry declined (see also Bowen 2000). Indeed, it declined to the point, Pitcher notes, where significant portions of the peasantry shifted their support from the Mozambican Liberation Front (FRELIMO), the governing party, to the Mozambican National Resistance 


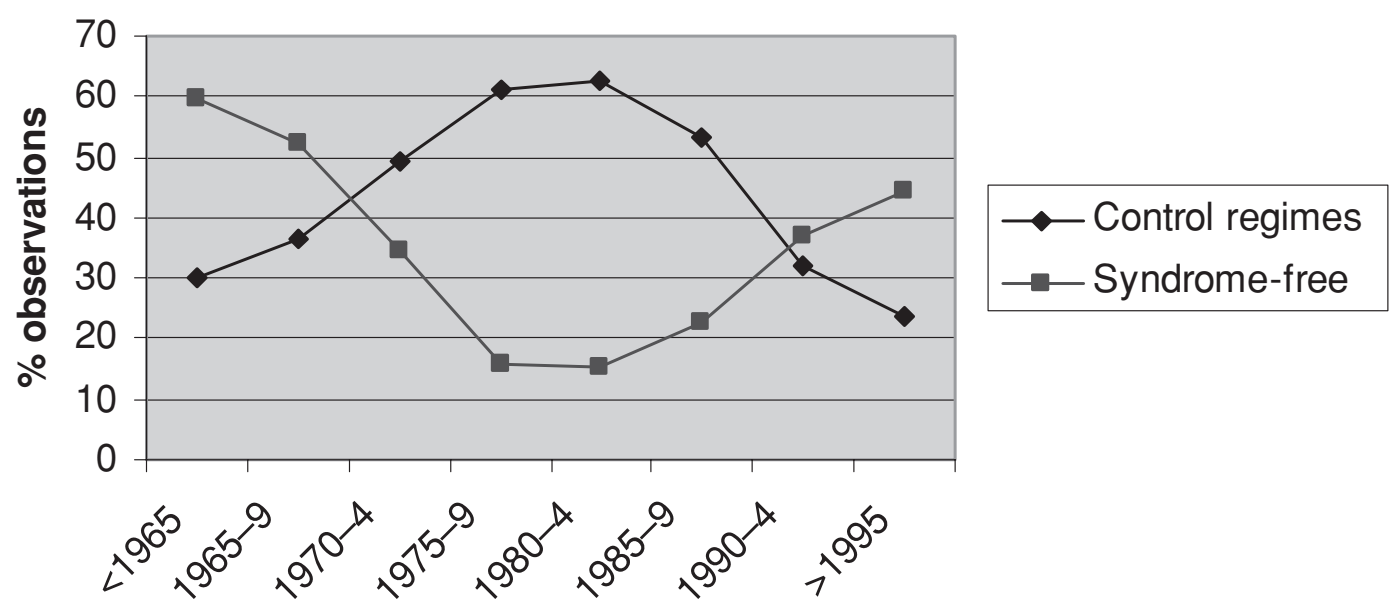

Figure 4.1 Policy regimes over time, 1965-1995

(RENAMO), an armed movement sworn to its forceful overthrow (see also Schutz 1995; Hall and Young 1997).

\section{Temporal and political correlates}

This section depicts the incidence of control regimes, comparing the frequency with which they were adopted, by time period and by type of political system. The pattern of variation points to forces that may account for the selection of such policies - and thus, too, for their subsequent abandonment.

As seen in figure 4.1, governments in the mid-1970s through to the mid1980s were more likely to adopt control regimes than were governments in the 1960s or 1990s.

As seen in figures 4.2 and 4.3, control regimes were more likely to be adopted by authoritarian governments: those based on no-party governments or single-party systems (figure 4.2) or military regimes (figure 4.3). Governments in countries with competitive political systems (figure 4.2) and civilian regimes (figure 4.3) were more likely to adopt policies judged "syndrome-free."

Not only has the choice of policy syndromes varied over the postindependence period; so too has the structure of political institutions (figures 4.4 and 4.5). In particular, single-party systems became increasingly scarce and competitive systems more common toward the end of the twentieth century.

6 The relationship between policy choice and political institutions is statistically significant in all cases. 


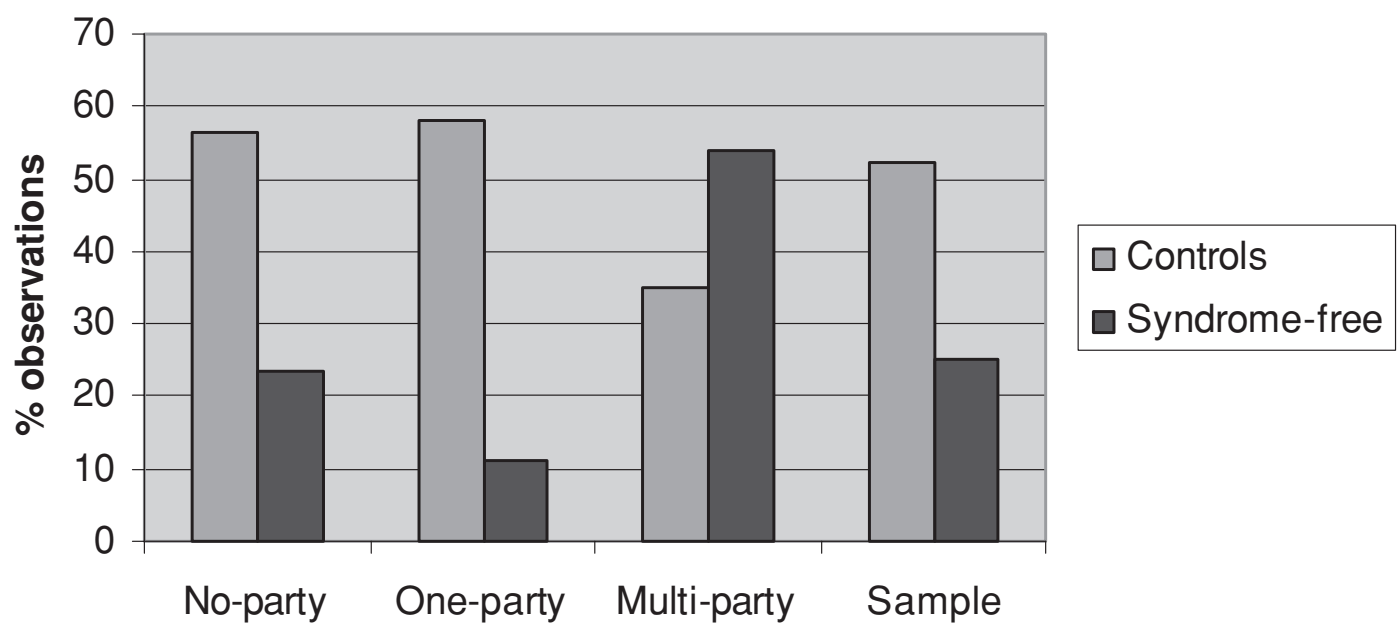

Figure 4.2 Policy choice and political system

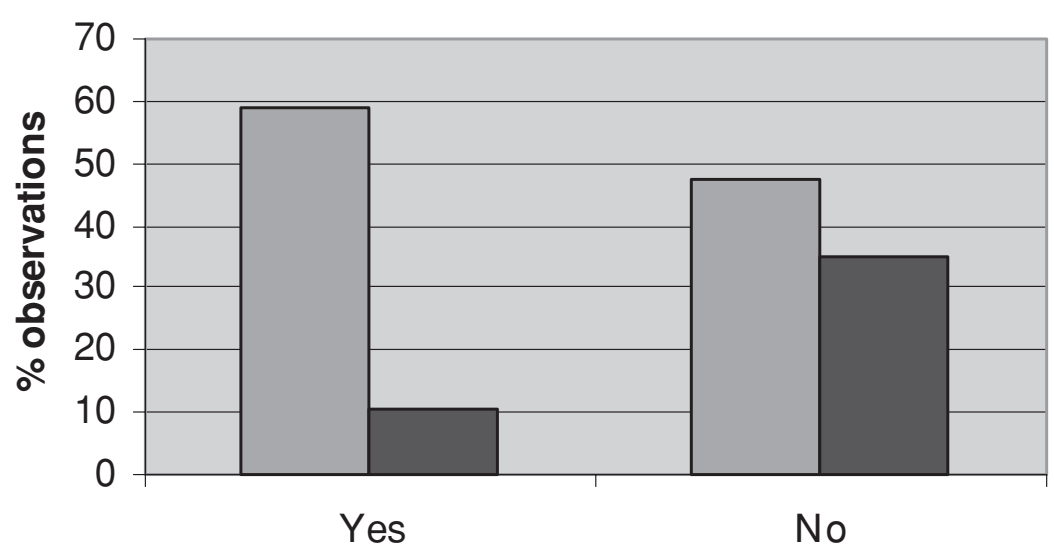

$\square$ Controls

Syndrome-free

\section{Military government?}

Figure 4.3 Military government and policy regime

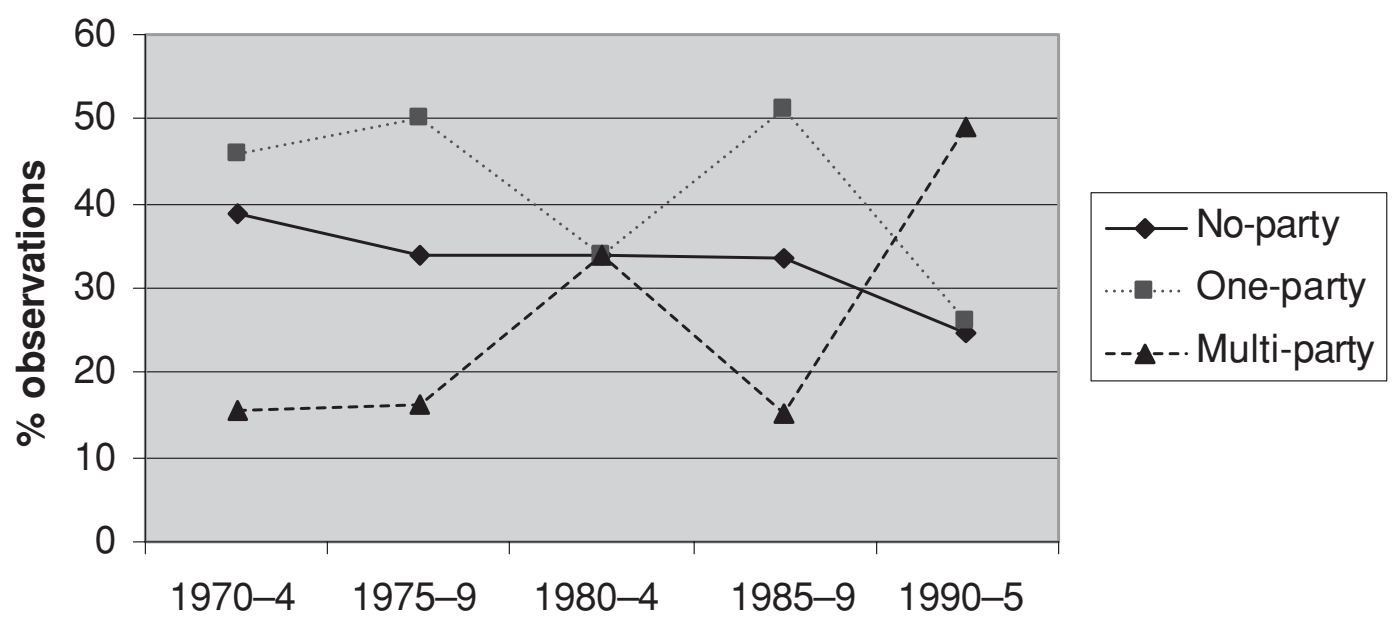

Figure 4.4 Party systems over time, 1970-1995 
Table 4.8 The variables.

\begin{tabular}{llcllc}
\hline & $\begin{array}{l}\text { Number of } \\
\text { observations }\end{array}$ & Mean & Std dev. & Min. & Max. \\
\hline Control regime & 1,196 & 0.510 & 0.501 & 0 & 1 \\
Syndrome-free & 1,163 & 0.251 & 0.434 & 0 & 1 \\
No-party system & 1,196 & 0.313 & 0.463 & 0 & 1 \\
Single-party system & 1,196 & 0.392 & 0.483 & 0 & 1 \\
Regional polarization & 1,118 & 0.372 & 0.484 & 0 & 1 \\
Privileged region & 1,195 & 0.891 & 0.311 & 0 & 1 \\
President from the non-privileged region & 977 & 0.570 & 0.495 & 0 & 1 \\
Socialism & 1,115 & 0.289 & 0.450 & 0 & 1 \\
Military head of state & 1,103 & 0.441 & 0.497 & 0 & 1 \\
Cold War & 1,196 & 0.692 & 0.462 & 0 & 1 \\
\hline
\end{tabular}

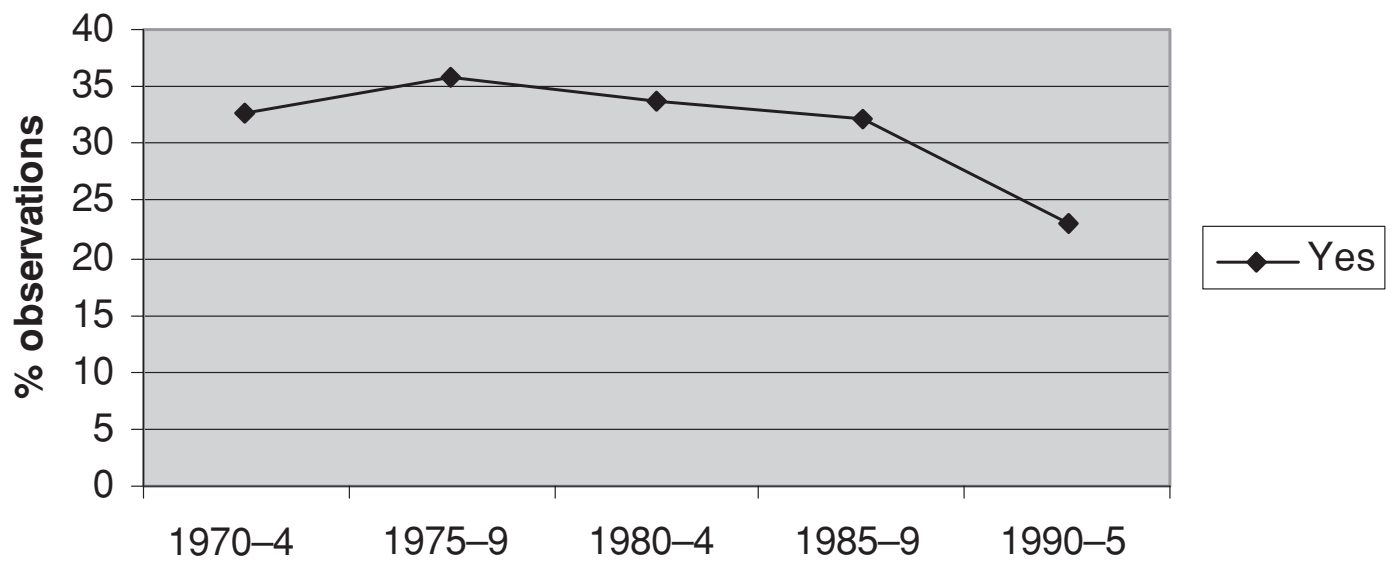

Figure 4.5 Military governments over time, 1970-1995

Because both policy choices and institutions have co-varied with time, the relationship between them may, of course, be spurious. To address this concern, we therefore turn to multivariate analysis. Table 4.8 describes the variables employed in subsequent models.

As demonstrated in table 4.9, when period dummies are entered into the equation, the relationship between type of political system and the choice of policy regime remains significant. The coefficients of these dummies capture the temporal pattern of policy choice, with the period before 1975 forming the reference category. The estimates in columns (1) and (3) confirm that governments were more likely to adopt control regimes during the 1970s and 1980s and that they became significantly less likely to adopt such policies in the 1990s. The coefficients in columns (2) and (4) suggest that the trajectory marking the adoption of syndrome-free policy-making traced a mirror image of that traced by the adoption of control regimes. 
Table 4.9 Patterns of policy-making. (conditional logistic estimation)

\begin{tabular}{lcccc}
\hline Dependent variable & $\begin{array}{c}\text { Control regime } \\
(1)\end{array}$ & $\begin{array}{c}\text { Syndrome-free } \\
(2)\end{array}$ & $\begin{array}{c}\text { Control regime } \\
(3)\end{array}$ & $\begin{array}{c}\text { Syndrome-free } \\
(4)\end{array}$ \\
\hline No-party system & 0.628 & -1.208 & & \\
Single-party system & $(3.56)^{* *}$ & $(6.62)^{* *}$ & & \\
& 0.688 & -2.021 & & -0.983 \\
Cold War & $(4.05)^{* *}$ & $(10.16)^{* *}$ & & $(6.19)^{* *}$ \\
& 0.902 & -0.480 & 1.096 & -1.676 \\
Military head of state & $(6.41)^{* *}$ & $(2.98)^{* *}$ & $(7.76)^{* *}$ & $(9.61)^{* *}$ \\
& & & 0.488 & 0.189 \\
Constant & & & $(3.80)^{* *}$ & $(1.38)$ \\
& -1.046 & 0.365 & -0.920 & 1038 \\
\hline
\end{tabular}

Absolute value of $z$-statistics in parentheses.

* Significant at $5 \%$; ${ }^{* *}$ significant at $1 \%$.

Of particular interest, however, are the coefficients on the institutional measures. In columns (1) and (2), the dummy variable indicating the presence of a competitive political system is subsumed by the constant term. The coefficients on the "no-party" and "single-party" variables indicate that the adoption of control regimes is significantly associated with the structure of political competition and that non-competitive systems were far less likely to adopt policies judged to be "syndrome-free." In columns (3) and (4), the coefficient on the variable indicating a military head of state suggests that military governments were significantly more likely to impose control regimes than were civilian. Taken together, the estimates in table 4.9 thus suggest a relationship between authoritarian forms of government and a preference for regulatory regimes.

\subsection{A closer look}

\subsubsection{Early adopters}

The first countries to adopt control regimes included the West African states of Ghana, Guinea, and Mali and East African nations such as Tanzania and Uganda. They also included Congo (Brazzaville). The leaders of these governments viewed themselves as socialist and adopted much of the language and some of the institutions of command-and-control economies.

As noted in the country studies in volume 2, socialist governments imposed control regimes. The Convention People's Party (CPP) that ruled 
Ghana under Kwame Nkrumah listed among its objectives the creation of "a Socialist State $[$ sic] in which all men and women shall have equal opportunity and where there will be no capitalist exploitation" (Aryeetey and Fosu 2005). The ruling parties of Tanzania, Zambia, and Uganda adopted "African socialist" manifestos in the mid-1960s; while the Movement National de la Révolution, the governing party in the Republic of Congo, formerly endorsed Marxism-Leninism in 1968 (Tsassa and Yamb 2007), as did the Parti de la Révolution Populaire in Benin and FRELIMO in Mozambique in the mid1970s. In each case, the result was the imposition of control regimes. As noted by Dossou and Sinzogan, with Mensah (2007: 3-4) in their study of Benin, when "socialism was proclaimed as the 'route to development' and Marxism-Leninism the 'philosophical guide,' then there began a policy of 'planification' with ambitious objectives." And the state then became "omnipotent ... with little regard for the interests of the private sector."

The commitment of governments to socialist policies at home was matched by a commitment to non-alignment abroad. As evidenced most vividly, perhaps, by the Congo (Kinshasa) crisis, almost immediately after independence in the early 1960s, the global conflict between capitalism and socialism intruded into the politics of Africa. The independence that its nations had just won now appeared threatened. The states that adopted control regimes numbered among those who most vigorously protested the intrusion of the great powers and advocated a policy of non-alignment in global affairs.

These governments also numbered among the most active opponents of the minority regimes that clung to power in Southern Africa. They channeled funds to liberation movements; maintained schools in which political activists could learn from the histories of the liberation struggles in China, Algeria, and Vietnam; and gave asylum to leaders who faced jail - or worse at home. Several provided bases where military units could train in preparation for re-deployment to their homelands.

The choice of economic policies by these "early adopters" of control regimes thus fits into a broader profile. The governments that adopted control regimes stood among the charter members of the so-called "Casablanca group." They sought Africa's liberation and championed the cause of African unity. Their adoption of interventionist economic policies appears to reflect their determination to transform the continent.

\subsubsection{Embattled reformers}

As noted in figure 4.1, the frequency with which governments adopted regulatory regimes increased from roughly 30 percent at the end of the 1960 s to over 60 percent by the end of the 1970s. One reason for this increase was the tendency of regimes that were, quite literally, embattled to regulate their economies. Both Ethiopia and Somalia - two nations fighting each 
Table 4.10 Ideology and patterns of policy-making. (conditional logistic estimation)

(1)
(2) Syndrome-free
(3)

(4)

\begin{tabular}{lcccc} 
Dependent variable & Control regime & Syndrome-free & Control regime & Syndrome-free \\
\hline No-party system & 0.751 & -1.186 & & \\
Single-party system & $(1.78)$ & $(2.67)^{* *}$ & & \\
& 1.105 & -0.885 & & \\
Socialist & $(2.48)^{*}$ & $(2.14)^{*}$ & & -2.533 \\
& 2.484 & -2.455 & 2.731 & $(4.79)^{* *}$ \\
Cold War & $(4.70)^{* *}$ & $(4.84)^{* *}$ & $(5.24)^{* *}$ & -2.429 \\
& 2.753 & -1.791 & 3.007 & $(6.92)^{* *}$ \\
Military head of state & $(8.48)^{* *}$ & $(5.38)^{* *}$ & $(9.06)^{* *}$ & -2.414 \\
& & & 0.736 & $(5.23)^{* *}$ \\
Observations & 641 & 562 & $(1.84)$ & 555 \\
Number of countries & 26 & 23 & 631 & 23 \\
\hline
\end{tabular}

Absolute value of $z$-statistics in parentheses.

* Significant at $5 \%$; ${ }^{* *}$ significant at $1 \%$.

other - adopted socialist ideologies and imposed control regimes in order to mobilize for war. To these nations could be added Angola, Mozambique, and Guinea-Bissau, whose military forces in the mid-1970s defeated those of Portugal. The governments of these nations sought to over-ride market forces in order to mobilize for war. Adding further impetus to their decision was the desire of some to signal their good faith to socialist countries abroad and thereby attract military and financial backing. ${ }^{7}$

Table 4.10 captures the relationship between the ideological commitment of the government in power and the pattern of policy-making.

\section{The politics of economics}

This section has two parts. The first addresses a paradox that has lurked just beneath the surface of the discussion thus far: the seeming willingness of socialist governments, with their commitment to economic equality, to

\footnotetext{
${ }^{7}$ In other instances, it is difficult to detect systematic reasons for the adoption of control regimes. In the case of Kenya, the reasons appear to derive from anxiety concerning food supplies; in that of the Côte d'Ivoire, they appear to be associated with the launching of agricultural projects and industrial schemes following the coffee boom of the mid-1970s. Rwanda, Chad, and Burundi may belong to the class of "embattled" regimes; Senegal, Madagascar, and Mauritius (1960-70) do not. In such instances, the reasons remain as idiosyncratic and therefore difficult to explain.
} 
undermine the well-being of peasants, the poorest of the poor in Africa. Untangling this paradox clarifies the role of political interests in the selection of government policies. The second illustrates the importance of pressures for redistribution, which also appear to promote the adoption of control regimes.

\subsection{A fruitful paradox}

As seen in table 4.10, socialist governments in Africa tend to impose control regimes. They therefore tend to adopt policies that lower the economic wellbeing of the peasantry, the poorest of their citizens, and those therefore with the most compelling claim for public assistance. ${ }^{8}$ Addressing the disjuncture between the values and the choices of socialist governments brings into sharp focus the political forces that drive policy choices.

The discussion can proceed in several quick steps.

\subsubsection{In general}

The core of Africa's political regimes was composed of the government, industry, and organized labor. While accounting for less than 40 percent of the GDP of a typical African state and less than 20 percent of the population, these urban-based interests nonetheless dominated policy-making in the post-independence period:

Governments provide services and, for the most part, public services remain un-priced. Their biggest cost is labor. To defend their budgets, governments therefore adopt policies that lowered the cost of labor.

Industries employ capital and labor to produce commodities. All else being equal, a decrease in the costs of labor results in an increase in profits. Industry therefore joins government in favoring policies that lower the costs of labor. Labor favors policies that defend the real value of workers' incomes. Given the income of most wage earners in Africa, workers devote a large portion of their expenditures to food.

In seeking to reward the core coalition, governments therefore championed policies that secured low priced food.

\subsubsection{In particular}

Socialist governments were tightly integrated with the other portions of the core coalition:

8 This tendency has been noted by others. See, for example, Mitrany (1961). 
Socialist governments were more likely to nationalize existing firms and to invest in new industries than were others. To a greater degree than other governments, their interests therefore aligned with those of industrial firms.

Socialist governments aspired to the provision of higher levels of health care, education, and other services than did most other governments. As a result, they hired more workers.

As a matter of principle, socialist governments endorsed the interests of workers. And as a matter of practice, socialist parties maintained close ties with organized labor and trade unions based in both private industry and the public services.

Socialist governments therefore possessed a strong interest in adopting policies that lowered the costs of food, even though lowering the incomes of farmers.

The policies that enabled socialist regimes to consolidate their core constituency violated their ideological commitments. That they did so testifies to the power of the political interests that dominated policy-making in the post-independence period. These industries were urban-based, industrybased, and located in the towns, and they possessed close ties to regimes in power.

Having limned the political foundations of control regimes, a second question arises: given the economic costs of these policies, why did governments not abandon them? To comprehend this delay, one need ask only: would any member of the governing coalition have an incentive unilaterally to call upon the government to abandon them? More specifically: would any single player - industry, organized labor, or the government itself benefit by calling for higher prices for farmers? The answer is of course: "no." No politician would voluntarily defect from the ruling coalition, no firm unilaterally agree to higher costs, no trade unionist call for changes that would lower the incomes of labor. While socially costly, the choice of policies constituted an equilibrium.

\subsection{Regional redistribution}

Control regimes were employed for purposes of redistribution. Already noted is their use by governments to extract resources from rural dwellers and to transfer them to urban-based industries. Equally important, it would appear, is the use of these policies to transfer resources between regions.

As noted by Tsassa and Yamb (2007), politics in the Republic of the Congo is marked by rivalries between the poorly endowed North and the relatively prosperous South. Following the "Three Glorious Days" of August 1963, a "Conseil National de la Révolution" (CNR) took power and committed the government to building a socialist state. In pursuit of that objective, it created state monopolies to purchase crops at fixed prices; selling them at 
competitive prices, the center collected taxes from the North. Tsassa and Yamb (2007) note that to defend its monopoly position from new entrants and competitors, the bureaucracies drew on the power of both the army and police. In 1968, the military forcefully seized power. Headed by Marien Ngouabi, a Northerner, the ruling junta then began to install people from the North to key posts throughout the military, the government, and the parastatal sector. Politics was a matter of regional redistribution.

Togo provides another example (Gogué and Evlo 2007). Northern Togo is semi-arid, poor, and relatively unpopulated. The South produces the primary cash crops and contains the phosphate deposits that generate the majority of Togo's foreign exchange. It also contains the majority of Togo's population and, for historical reasons, a disproportion of its educated personnel. Most active portions of the independence movement had originated in the South, and it was a Southerner, Sylvanus Olympio, who became Togo's first President. In 1963, however, the military seized office. Gnassingbé Eyadéma was Olympio's rival and after a four-year interval he seized the presidency. Gnassingbé came from Kara, a district in the North. Through a mixture of inducement and intimidation - heavily balanced toward the latter - he rendered the state a means of extracting resources from the South to the benefit of himself and his Northern constituency.

Recalling the Kobou, Njinkeu, and Powo Fosso (2007) analysis of Cameroon, the discussion of Malawi by Chipeta and Mkandawire (2007), and Mwega and Ndung'u's (2007) portrayal of Kenya, we gain a keen appreciation of the extent to which regional competition drives politics in Africaand the policy choices of its governments.

Table 4.11 illustrates the relationship between policy choice and regional inequality. The variable "Privileged region" takes the value 1 when a nation exhibits a high level of regional inequality and 0 when it does not. The coefficient suggests that when there is a privileged region, governments are more likely to impose control regimes and less likely to adopt policies that are "syndrome-free." Note, too, the coefficient on the variable "Polarized region." A privileged region is coded as polarized when it is ethnically and religiously homogenous and distinctive. The coefficient suggests that cultural uniformity and distinctiveness add to the impact of regional inequality, producing a stronger tendency to introduce control regimes.

Table 4.12 suggests that in countries where the chief executive is from a region that is relatively poor, governments are again more likely to adopt control regimes (column (1)) and less likely to adopt policies that remain syndrome-free (column (2)). The coefficient in column (1) is statistically significant. The coefficient in column (3), moreover, suggests that when the presidency shifts from a privileged to a non-privileged region, then the government is significantly more likely to impose regulatory controls. 
Table 4.11 Regional differentiation and patterns of policy-making. (logistic estimation, pooled sample).

\begin{tabular}{llccc}
\hline Dependent variable & $\begin{array}{c}\text { Control regime } \\
(1)\end{array}$ & $\begin{array}{c}\text { Syndrome-free } \\
(2)\end{array}$ & $\begin{array}{c}\text { Control regime } \\
(3)\end{array}$ & $\begin{array}{c}\text { Syndrome-free } \\
(4)\end{array}$ \\
\hline No-party system & 0.566 & -1.339 & & \\
Single-party system & $(2.97)^{* *}$ & $(5.79)^{* *}$ & & \\
Privileged region & 0.485 & -1.478 & & -2.640 \\
& $(2.50)^{*}$ & $(6.36)^{* *}$ & & $(9.02)^{* *}$ \\
Polarized region & 1.505 & -2.410 & 1.530 & -0.814 \\
& $(5.44)^{* *}$ & $(8.16)^{* *}$ & $(5.78)^{* *}$ & $(3.81)^{* *}$ \\
Socialist & 0.599 & -1.215 & 0.573 & -1.704 \\
& $(3.81)^{* *}$ & $(5.65)^{* *}$ & $(3.66)^{* *}$ & $(6.09)^{* *}$ \\
Cold War & 1.524 & -1.779 & 1.391 & -1.051 \\
& $(8.54)^{* *}$ & $(6.41)^{* *}$ & $(7.75)^{* *}$ & $(5.51)^{* *}$ \\
Military head of state & 0.994 & -0.601 & 1.118 & -1.742 \\
& $(6.28)^{* *}$ & $(3.16)^{* *}$ & $(7.15)^{* *}$ & $(8.47)^{* *}$ \\
Constant & & & 0.277 & 3.086 \\
& & & $(1.90)$ & $(9.76)^{* *}$ \\
Observations & -2.771 & 3.033 & -2.592 & 1003 \\
\hline
\end{tabular}

Absolute value of $z$-statistics in parentheses.

* Significant at $5 \%$; ${ }^{* *}$ significant at $1 \%$.

Table 4.13 reports marginal effects, thus enabling us to gain a sense of the magnitude of the coefficients contained in table 4.12. The coefficients confirm the importance of party competition; in its absence, the likelihood of adopting a control regime or of abandoning syndrome-free patterns of policy-making rises by about 20 percentage points. Regional inequality increases the likelihood of control regimes by about 15 percentage points; cultural polarization adds an additional 20 percentage points. The impact of these variables is both less and less precisely estimated under military governments than when there are civilian regimes. The results also confirm the arguments of Mwase and Ndulu (2007): both ideology and "the times" appear to have a significant impact upon patterns of policy-making.

\subsection{Discussion}

The political forces that underpin the choice of control regimes thus appear to arise from three sources. One is ideology. High levels of government intervention occur when governments find principled reasons for overriding the allocations generated by markets. A second is the power of 
Table 4.12 Presidential origin and patterns of policy-making.

(logistic estimation, pooled sample).

\begin{tabular}{llccc}
\hline Dependent variable & $\begin{array}{c}\text { Control regime } \\
(1)\end{array}$ & $\begin{array}{c}\text { Syndrome-free } \\
(2)\end{array}$ & $\begin{array}{c}\text { Control regime } \\
(3)\end{array}$ & $\begin{array}{c}\text { Syndrome-free } \\
(4)\end{array}$ \\
\hline No-party system & 0.532 & -1.482 & & \\
Single-party system & $(2.29)^{*}$ & $(5.76)^{* *}$ & & \\
& 0.585 & -1.625 & & \\
President from the & $(2.55)^{*}$ & $(6.40)^{* *}$ & & -0.123 \\
non-privileged region & 0.743 & -0.214 & 0.806 & $(0.60)$ \\
Socialist & $(4.44)^{* *}$ & $(1.05)$ & $(4.63)^{* *}$ & -1.558 \\
& 1.823 & -1.506 & 1.697 & $(5.52)^{* *}$ \\
Polarized region & $(8.85)^{* *}$ & $(5.41)^{* *}$ & $(8.12)^{* *}$ & -0.678 \\
Cold War & 1.001 & -1.069 & 0.987 & $(3.19)^{* *}$ \\
& $(5.76)^{* *}$ & $(4.93)^{* *}$ & $(5.65)^{* *}$ & -1.026 \\
Military head of state & 1.023 & -0.568 & 1.189 & $(5.20)^{* *}$ \\
& $(5.76)^{* *}$ & $(2.74)^{* *}$ & $(6.85)^{* *}$ & -1.374 \\
Constant & & & -0.172 & $(6.22)^{* *}$ \\
& & & $(1.01)$ & 0.376 \\
Observations & -1.924 & 0.831 & -1.519 & $(1.83)$ \\
\hline
\end{tabular}

Absolute value of $z$-statistics in parentheses.

* Significant at $5 \%$; ${ }^{* *}$ significant at $1 \%$.

organized interests. In a political world in which governments need not compete for the support of a broad electorate, interest groups constitute the primary means by which political preferences shape policy choices. And in a game best characterized as the interplay of political interests, it is those that are organized that prevail. The third is regional inequality. It generates incentives to adopt policies designed to overcome the economic impact of disparate endowments and to create political institutions with the power to elicit the transfer of resources. Authoritarianism; demands for redistribution between town and country, rich region and poor; and governmental intervention in markets - these tendencies co-vary. They appear to have shaped the political conduct and economic performance of governments in post-independence Africa.

\section{Conclusion}

This analysis not only furnishes insight into the political logic underlying control regimes but also into the politics of late-twentieth-century reform. 
Table 4.13 Marginal effects on patterns of policy-making. (logistic estimation, pooled sample).

\begin{tabular}{llccc}
\hline Dependent variable & $\begin{array}{c}\text { Control regime } \\
(1)\end{array}$ & $\begin{array}{c}\text { Syndrome-free } \\
(2)\end{array}$ & $\begin{array}{c}\text { Control regime } \\
(3)\end{array}$ & $\begin{array}{c}\text { Syndrome-free } \\
(4)\end{array}$ \\
\hline No-party system & 0.191 & -0.180 & & \\
Single-party system & $(4.22)^{*}$ & $(7.29)^{* *}$ & & \\
& 0.221 & -0.226 & & -0.012 \\
President from the & $(4.76)^{*}$ & $(7.62)^{* *}$ & & $(0.48)$ \\
non-privileged region & 0.151 & -0.021 & 0.176 & -0.177 \\
Socialist & $(4.00)^{* *}$ & $(0.82)$ & $(4.53)^{* *}$ & $(8.20)^{* *}$ \\
& 0.372 & -0.129 & 0.363 & -0.087 \\
Polarized region & $(12.33)^{* *}$ & $(5.48)^{* *}$ & $(11.85)^{* *}$ & $(3.64)^{* *}$ \\
Cold War & 0.224 & -0.163 & 0.217 & -0.186 \\
& $(6.43)^{* *}$ & $(7.28)^{* *}$ & $(6.20)^{* *}$ & $(5.82)^{* *}$ \\
Military head of state & 0.221 & -0.19 & 0.196 & -0.178 \\
& $(6.68)^{* *}$ & $(5.00)^{* *}$ & $(5.56)^{* *}$ & $(6.58)^{* *}$ \\
Constant & & & -0.025 & 0.376 \\
& & & $(0.64)$ & $(1.83)$ \\
Observations & -1.924 & 0.831 & -1.519 & 820 \\
\hline
\end{tabular}

Absolute value of $z$-statistics in parentheses.

* Significant at $5 \%$; ${ }^{* *}$ significant at $1 \%$.

As noted in chapter 9, with the end of the Cold War global opinion swung in favor of free market policies and competitive political systems. An implication of the arguments in this chapter is that these economic and political reforms of necessity took place together.

When contemplating this proposition, it is useful to cite three cases. The first is policy change in Mozambique; the second, policy reform in Ghana; and the third, policy-making in Botswana.

Mozambique's peasantry faced costs of organizing as high as those faced by the peasantry in other countries. But RENAMO based itself in the rural areas when mounting its armed opposition to the government. RENAMO could successfully operate in the rural areas because it drew logistical support from abroad. What support many peasants could give, however, they did give, and FRELIMO, the governing party, faced the prospect of losing their political allegiance, given its insistence on measures that the peasants opposed (Schultz 1976; Hall and Young 1997; Pitcher 2002). One reason that FRELIMO relaxed and then abandoned its commitment to villagization was that the policies fueled support for RENAMO, its political rival. 
Elsewhere peasants lacked such an advocate - organized, armed, and able to resist the governing party - and governments had less reason to alter their policies.

First as a military ruler and then as a head of a single party regime, Rawlings deployed his security services in Ghana to impose price controls, shut down black markets, and evacuate crops from the countryside for sale in urban markets. In face of these policies, the economy still failed to grow and the government began to contemplate abandoning its dirigiste policies. For Rawlings, abandoning a control regime was tantamount to abandoning his urban-based, industry-based, class-based constituency and the socialist principles that legitimated his policy commitments.

The solution that Rawlings devised is notable. To defend his political future while altering his public policies, Rawlings had to build a rural base for his governing party. Beginning by organizing village political committees manned by political militants, he then introduced elected local councils. When he later introduced elections for the parliament and presidency, he had therefore already put in place political organizations throughout the townships and villages. Given the structure of Ghana's economy and the composition of its population, rural voters outnumbered urban. For Rawlings, democratization therefore provided a means of shifting from an urbanbased constituency, which was hurt by economic reform, to a rural political base, which benefited from them. It provided a means of surviving politically while abandoning a control regime (Leith and Lofchie 1991; Rothchild 1991, 1995; Shillington 1992; Herbst 1993; Oquaye 1995; Gyimah-Boadi 1998; and Aryeetey and Fosu 2007).

If Ghana provides evidence that the abandonment of control regimes creates incentives for political reform, then Botswana provides evidence of how open political competition creates incentives to avoid the extractive policies in the first place. As stated by Maipose and Matsheka (2007):

The leadership in the ruling party had considerable interest in promoting their own version of good government. Because the government knew that it must stand for election every five years, the ruling party pursued policies it believed would gain it the political support necessary to defeat its opponents, seeking "profit" in the form of "political income." The priorities of the key rural development programs, such as the Arable Land Development Programme and the Accelerated Rural Development Programme, initiated during this period, and attention given to the cattle industry, were not biased against rural areas. (2007: 10)

Control regimes can not be sustained when policy results from competition between politicians who had every reason to bid for political majorities. In Africa, farmers constitute that majority, and their interests are violated by these policies. 
The introduction of political competition and the abandonment of control regimes thus went together in late-twentieth-century Africa.

\section{References}

Alemayehu Geda (2007), "The Political Economy of Growth in Ethiopia," chapter 4 in Benno J. Ndulu, Stephen A. O'Connell, Jean-Paul Azam, Robert H. Bates, Augustin Kwasi Fosu, Jan Willem Gunning, and Dominique Njinkeu, eds., The Political Economy of Economic Growth in Africa, 1960-2000, vol. 2. Cambridge: Cambridge University Press

Aryeetey, Ernest and Augustin K. Fosu (2005), “Ghana,” African Economic Research Consortium, Nairobi

(2007), "Economic Growth in Ghana," chapter 9 in Benno J. Ndulu, Stephen A. O'Connell, Jean-Paul Azam, Robert H. Bates, Augustin Kwasi Fosu, Jan Willem Gunning, and Dominique Njinkeu, eds., The Political Economy of Economic Growth in Africa, 1960-2000, vol. 2. Cambridge: Cambridge University Press

Azam, Jean-Paul and Nadjiounom Djimtoïngar (2007), "Cotton, War, and Growth in Chad, 1960-2000,” chapter 3 in Benno J. Ndulu, Stephen A. O’Connell, Jean-Paul Azam, Robert H. Bates, Augustin Kwasi Fosu, Jan Willem Gunning, and Dominique Njinkeu, eds., The Political Economy of Economic Growth in Africa, 1960-2000, vol. 2. Cambridge: Cambridge University Press

Bates, Robert H. and Paul Collier (1991), "The Case of Zambia," in Robert H. Bates and Anne O. Krueger, Political and Economic Interactions in Economic Policy Reform. Oxford: Blackwell

Bowen, Merle L. (2000), The State against the Peasantry: Rural Struggles in Colonial and Postcolonial Mozambique. Charlottesville, VA: University of Virginia Press

Chipeta, Chinyamata and Mjedo Mkandawire (2007), "Man-made opportunities and Growth in Malawi,” chapter 5 in Benno J. Ndulu, Stephen A. O'Connell, Jean-Paul Azam, Robert H. Bates, Augustin Kwasi Fosu, Jan Willem Gunning, and Dominique Njinkeu, eds., The Political Economy of Economic Growth in Africa, 1960-2000, vol. 2. Cambridge: Cambridge University Press

Davies, Victor (2007), "Sierra Leone's Economic Growth Performance, 1961-2000," chapter 19 in Benno J. Ndulu, Stephen A. O’Connell, Jean-Paul Azam, Robert H. Bates, Augustin Kwasi Fosu, Jan Willem Gunning, and Dominique Njinkeu, eds., The Political Economy of Economic Growth in Africa, 1960-2000, vol. 2. Cambridge: Cambridge University Press

de Sousa, Clara and José Sulemane (2005), "Mozambique’s Growth Performance, 1960-1996," chapter 24 in Benno J. Ndulu, Stephen A. O'Connell, JeanPaul Azam, Robert H. Bates, Augustin Kwasi Fosu, Jan Willem Gunning, and Dominique Njinkeu, eds., The Political Economy of Economic Growth in Africa, 1960-2000, vol. 2. Cambridge: Cambridge University Press

Dodge, Doris Jansen (1977), Agricultural Policy and Performance in Zambia. Berkeley, CA: Institute of International Studies, University of California

Dossou, Antonin S., Jean-Yves Sinzogan, with Sylviane Mensah (2007), "Economic Growth in Benin: Lost Opportunities," chapter 22 in Benno J. Ndulu, Stephen A. O'Connell, Jean-Paul Azam, Robert H. Bates, Augustin Kwasi Fosu, Jan 
Willem Gunning, and Dominique Njinkeu, eds., The Political Economy of Economic Growth in Africa, 1960-2000, vol. 2. Cambridge: Cambridge University Press

Doumbouya, Sékou F. and Fodé Camara (2007), "Explaining Economic Growth in Africa: The Case of Guinea," chapter 17 in Benno J. Ndulu, Stephen A. O'Connell, Jean-Paul Azam, Robert H. Bates, Augustin Kwasi Fosu, Jan Willem Gunning, and Dominique Njinkeu, eds., The Political Economy of Economic Growth in Africa, 1960-2000, vol. 2. Cambridge: Cambridge University Press

Fosu, Augustin and Stephen A. O'Connell (2006), "Explaining African Economic Growth: The Role of Anti-Growth Syndromes," in François Bourguignon and Boris Pleskovic, eds., Growth and Integration: Annual World Bank Conference on Development Economics 2006. Washington, DC: The World Bank

Gogué, Tchaboure Aimé and Kodjo Evlo (2005), “Togo.” Africa Economic Research Consortium, Nairobi

(2007), “Togo: Lost Opportunities for Growth," chapter 14 in Benno J. Ndulu, Stephen A. O’Connell, Jean-Paul Azam, Robert H. Bates, Augustin Kwasi Fosu, Jan Willem Gunning, and Dominique Njinkeu, eds., The Political Economy of Economic Growth in Africa, 1960-2000, vol. 2. Cambridge: Cambridge University Press

Gyimah-Boadi, Emmanuel (1998), "Managing Electoral Conflicts: Lessons from Ghana," in T. D. Sisk and A. Reynolds, eds., Elections and Conflict Management in Africa. Washington, DC: United States Institute of Peace Press

Hall, Margaret and Tom Young (1997), Confronting Leviathan: Mozambique since Independence. Athens, OH: Ohio University Press

Herbst, Jeffrey (1993), The Politics of Reform in Ghana. Berkeley, CA and Los Angeles, CA: University of California Press

Killick, Tony (1978), Development Economics in Action. London: Heinemann

Kobou, Georges, Dominique Njinkeu, and Bruno Powo Fosso (2007), “The Political Economy of Cameroon's Post-independence Growth," chapter 16 in Benno J. Ndulu, Stephen A. O'Connell, Jean-Paul Azam, Robert H. Bates, Augustin Kwasi Fosu, Jan Willem Gunning, and Dominique Njinkeu, eds., The Political Economy of Economic Growth in Africa, 1960-2000, vol. 2. Cambridge: Cambridge University Press

Krueger, Anne O., Maurice Schiff, and Alberto Valdes, eds. (1992), The Political Economy of Agricultural Pricing Policies, 5 vols. Baltimore, MD: Johns Hopkins University Press for the World Bank

Leith, Clark and Michael Lofchie (1993), “The Case of Ghana," in Robert H. Bates and Anne O. Krueger, Political and Economic Interactions in Economic Policy Reform. Oxford: Blackwell

Lofchie, Michael F. (1989), The Policy Factor: Agricultural Performance in Kenya and Tanzania. Boulder, CO: Lynne Rienner

MacGaffey, Janet (1991), The Real Economy of Zaire. Philadelphia, PA: Unversity of Pennsylvania Press

Maipose, Gervase S. and Thapelo C. Matsheka (2007), "The Indigenous Developmental State and Growth in Botswana," chapter 15 in Benno J. Ndulu, Stephen 
A. O'Connell, Jean-Paul Azam, Robert H. Bates, Augustin Kwasi Fosu, Jan Willem Gunning, and Dominique Njinkeu, eds., The Political Economy of Economic Growth in Africa, 1960-2000, vol. 2. Cambridge: Cambridge University Press

McHenry, Dean E. (1994), Limited Choices: The Political Struggle for Socialism in Tanzania. Boulder, CO: Lynne Reinner

Mitrany, David (1961), Marx Against the Peasant. New York: Collier

Mwanawina, Inyambo and James Mulungushi (2007), "Zambia," chapter 27 in Benno J. Ndulu, Stephen A. O'Connell, Jean-Paul Azam, Robert H. Bates, Augustin Kwasi Fosu, Jan Willem Gunning, and Dominique Njinkeu, eds., The Political Economy of Economic Growth in Africa, 1960-2000, vol. 2. Cambridge: Cambridge University Press

Mwase, Nkunde and Benno J. Ndulu (2007), “Tanzania: Explaining Four Decades of Episodic Growth," chapter 13 in Benno J. Ndulu, Stephen A. O'Connell, Jean-Paul Azam, Robert H. Bates, Augustin Kwasi Fosu, Jan Willem Gunning, and Dominique Njinkeu, eds., The Political Economy of Economic Growth in Africa, 1960-2000, vol. 2. Cambridge: Cambridge University Press

Mwega, Francis M. and Njuguna S. Ndung'u (2007), "Explaining African Economic Growth Performance: The Case of Kenya," chapter 10 in Benno J. Ndulu, Stephen A. O'Connell, Jean-Paul Azam, Robert H. Bates, Augustin Kwasi Fosu, Jan Willem Gunning, and Dominique Njinkeu, eds., The Political Economy of Economic Growth in Africa, 1960-2000, vol. 2. Cambridge: Cambridge University Press

Nkurunziza, Janvier and Floribert Ngaruko (2007), "Why Has Burundi Grown So Slowly? The Political Economy of Redistribution," chapter 2 in Benno J. Ndulu, Stephen A. O'Connell, Jean-Paul Azam, Robert H. Bates, Augustin Kwasi Fosu, Jan Willem Gunning, and Dominique Njinkeu, eds., The Political Economy of Economic Growth in Africa, 1960-2000, vol. 2. Cambridge: Cambridge University Press

Oquaye, Mike (1995), "The Ghanaian Elections of 1992 - A Dissenting View," African Affairs 94: 255-75

Pitcher, M. Anne (2002), Transforming Mozambique. New York: Cambridge University Press

Rothchild, Donald (1995), "Rawlings and the Engineering of Legitimacy in Ghana," in I. W. Zartman, Collapsed States. Boulder, Co: Lynne Rienner

ed. (1991), Ghana: The Political Economy of Recovery. Boulder, CO: Lynne Rienner Samba Mamadou, Ousmane and Mahaman Sani Yakoubou (2007), "Climate Vulnerability, Political Instability, Investment, and Growth in a Landlocked, Sahelian Economy: Niger, 1960-2000," chapter 6 in Benno J. Ndulu, Stephen A. O’Connell, Jean-Paul Azam, Robert H. Bates, Augustin Kwasi Fosu, Jan Willem Gunning, and Dominique Njinkeu, eds., The Political Economy of Economic Growth in Africa, 1960-2000, vol. 2. Cambridge: Cambridge University Press

Schultz, Theodore W. (1976), Transforming Traditional Agriculture. New York: Arno Press 
Schutz, Barry (1995), "The Heritage of Revolution and the Struggle for Governmental Legitimacy in Mozambique," in I. W. Zartman, ed., Collapsed States. Boulder, Co: Lynne Rienner

Shillington, Kevin (1992), Ghana and the Rawlings Factor. London: Macmillan

Tsassa, Célestin and Benjamin Yamb (2007), "Croissance off-shore au Congo et économie rentière," chapter 25 in Benno J. Ndulu, Stephen A. O’Connell, Jean-Paul Azam, Robert H. Bates, Augustin Kwasi Fosu, Jan Willem Gunning, and Dominique Njinkeu, eds., The Political Economy of Economic Growth in Africa, 1960-2000, vol. 2. Cambridge: Cambridge University Press

Turok, B. (1979), Development in Zambia. London: Zed Press

World Bank (1975), Republic of Zambia: Agricultural and Rural Sector Survey. Washington, DC: The World Bank

(1982), Tanzania: Agricultural Sector Report. Washington, DC: The World Bank

(1994), Adjustment in Africa: Reform, Results, and the Road Ahead. Washington, DC: The World Bank 